\title{
How to Identify Negative Attitudes towards Inclusive Education: Critical Discourse Analysis of Russian Transcripts Using Role and Reference Grammar
}

\author{
Mariia Rubtcova (Corresponding author) \\ Department of Social Management and Planning, Faculty of Sociology, Saint Petersburg State University, Russian Federation \\ E-mail: spgbu@list.ru \\ Oleg Pavenkov
}

Department of Media Communications, Saint-Petersburg State Institute of Film and Television, Russian Federation

Julia Varlamova

Department of Foreign Languages, National Research University Higher School of Economics, Russian Federation

Valentina Kaisarova

Department of Management and Planning of Socio-Economic Processes, Faculty of Economics, Saint Petersburg State University, Russian Federation

Lidmila Volchkova

Department of Social Management and Planning, Faculty of Sociology, Saint Petersburg State University, Russian Federation

Galina Menshikova

Department of Social Management and Planning, Faculty of Sociology, Saint Petersburg State University, Russian Federation

Julia Denisova

Department of Social Management and Planning, Faculty of Sociology, Saint Petersburg State University, Russian Federation

Received: 19-04-2016

Published: 01-09-2016
Accepted: 27-06-2016

doi:10.7575/aiac.ijalel.v.5n.5p.183
Advance Access Published: July 2016

URL: http://dx.doi.org/10.7575/aiac.ijalel.v.5n.5p.183

\begin{abstract}
This paper presents the Role and Reference Grammar (RRG) analysis that aims to reveal possibilities required for carrying out the interdisciplinary research development within Critical Discourse Analysis (CDA). It takes a closer look at conflicts, considering the example of a conflict situation occurred in reaction to the opening of the inclusive academic programme at one of St. Petersburg's secondary schools. Role and Reference Grammar application demonstrates that the use of different verb types and macroroles has led to the various interpretations. These findings confirm that RRG could influence the increase of objectivity of the transcript analysis in qualitative social research. RRG provides new information which in combination with other methods can help us to understand the positions of participants involved into conflicts
\end{abstract}

Keywords: Role and Reference Grammar, Inclusive Education, Qualitative social research in Sociology of Management

\section{Introduction}

In the USSR parents were encouraged to provide institutional care for children with special needs. That was mainly due to the strict legal regulation that forced most of the children with special needs to leave general (regular) schools. Although the disabled people were affected by the existing legitimacy and "the first disability rights organizations were considered as dissidents (Raymond, 1989), all treatment decisions were based solely on recommendations carried out by doctors (Rubtcova et al, 2015a).

However, soon after the collapse of the Soviet Union, the attitude to the soviet medical system was estimated as extremely negative (Malinina et al, 2015; Pavenkov et al, 2015a; Pavenkov et al, 2015b). The majority of publications appeared in response to the criticism of social exclusion and stigmatization. Numerous studies on inclusive education in Russia emerged, that were used as a platform for placing special emphasis on civil rights. For example, Elena IarskiaSmirnova uses personal narratives of Russian mothers of children with disabilities in Saratov (Russia) in the period from 1995 to 1997 aimed at criticizing the inadequacy of Disability Framework in Russia. It has been proved that 
families who decide on upbringing children with special needs at home face social exclusion due to cultural stigma. Diagnosis of children as defective can lead to feelings of guilt on the part of the mothers (Iarskia-Smirnova, 1999). Johnson highlights that, in former Soviet states, many disabled children have to be placed in institutions for child care and treatment. Moreover, the rights of parents are violated by doctors and state authorities (Johnson, 2007). In addition, methods of self-empowerment people with disabilities in Soviet Russia have also been evaluated (Iarskia-Smirnova, 2001)

While the issue of children with disabilities raises some concerns, a group of western researchers report gradual improvements in this topical area. It can be explained that civil society has been exposed to «glasnost» movement and provide significant support to adults, particularly disabled veterans and children. Associational contributions and cooperation with local authority play more crucial role and lead to partial local successes added to increased influence on involving people with disabilities in determining their own lives (Smith-Davis, 2000; Roza, 2005; Thomson, 2006).

In the late 2000s, a number of comprehensive papers, describing inclusive education, emerged in Russia. The studies view inclusive education as an approach that is gradually accepted by the society, moreover teachers and parents agreed on addressing it as a meaningful idea (Alehina, 2012 a,b; Godovnikova, 2009). Many published works at that period sounded more and more optimistic, claiming the necessity of elaborate preparation for the adoption of inclusive education (e.g. Butenko \& Chistokhina, 2015).

The Federal Law "On Education in the Russian Federation" came into force on 1 September, 2013. Despite the law proclaims education for people with the limited possibilities of health and disability as one of the privileges of education system in Russian Federation, the problem of readiness of the Russian society to implement inclusive education remains one of the most debatable in education sector.

The key feature of Russian system is that it establishes and move towards existence its own training method that is comprised of techniques aimed to work with «special children» - the system of correctional pedagogy. The correctional pedagogy system was integrated in the Soviet era (Korkunov et al., 1998). Correctional pedagogy is based on the creation of separate schools for children with special needs and it still has a large number of supporters (Martianova \& Rubtcova, 2013).

In 2014 significant attempts to move towards inclusive education sparked mass protests on behalf of parents and teachers. In Moscow on 11 October, 2014 parents held a demonstration against the merger of correctional and general schools (RSD, 2015). Later on 26 October, 2014 many large Russian cities were already overtaken by the mass demonstrations (MK, 2015), which resulted in working out a petition in defense of Correcting Education in Moscow to Vice Prime Minister Olga Golodets and signing it by 14 thousand people (MK, 2015). Parents put forward claims to establish a moratorium on the reform of correctional school education. One of the major drawback of the demonstrations is that inclusive education has almost been removed from the agenda. The present paper seeks to show how the negation of inclusive education is formed in our daily practices through the reference to the Role and Reference Grammar.

Role and Reference Grammar (RRG) «posits a direct mapping between the semantic representation of a sentence and its syntactic representation» (Van Valin, 2007: 32). Van Valin focuses on the study of grammar and denies the possibility to reduce grammar to any other phenomena (like discursive processes, for example). Van Valin departs from Chomsky theory by making attempts not only to describe but also explain grammar competence, he also suggests that language cannot be simply reduced to grammar textbooks. So, «RRG may be labeled as a «structural-functionalist theory of grammar»; this is intended to situate it on a continuum of perspectives ranging from extreme formalist at one end to radical functionalist at the other» (Van Valin, 1993: 1).

In conflict situations, it is very crucial to be aware of how participants determine the situation themselves and which grammatical structures are of their primary preference. In this respect RRG might become a tool provided for conducting conflict analysis. On the one hand, representatives of many socio-humanitarian disciplines (for example, sociologists) seek to apply Critical Discourse Analysis (CDA) in their works, as stated by Van Dijk (Van Dijk, 2009, 2013). On the other hand, sociologists express concern about the growing tendency to reduce most of linguistic signs from CDA.

RRG is primarily based on data collection from different languages. «Russian is often cited as an example of a language with "free word order", where this term is normally understood to mean that variation in the order of arguments and the predicate does not affect the interpretation of the syntactic functions and semantic roles of the arguments» (Van Valin, 1993: 89). Padusheva has performed the detailed analysis of the Russian language differences and outlined prospects of the RRG analysis in Russian (1996, 2009a, 2009b). Meanwhile, there is considerable uncertainty with regard to importance of the mentioned above language differences (Rubtcova et al., 2016; Rubtsova et al., 2015a). This can be explained as Padusheva focuses primarily on distinctive features with the purpose of the other conception development on the RRG basis, which is identified as the main goal of the present paper (Padusheva, 2009b).

The objective of the study is to carry out an analysis of transcripts within the framework of RRG, in order to establish whether RRG can promote the deeper understanding of the conflict through the analysis of discourse.

The research question is the following:

- Can RRG analysis be useful as it performs an additional interpretation of discourse features in the conflict situation presented in transcripts? 


\section{Theoretical framework}

Critical Discourse Analysis (CDA) represents a version of the discourse research procedure addressed to investigating to what extent (obviously or latently) abuse of our social power and dominance can be realized in the form of discourse in social contexts. Representing a dissident approach, CDA is focused on understanding, explaining and finally results in resistance to social inequality (Van Dijk, 2013: 111). Ideological roots of CDA lie in Marxism and the Critical theory of society (the Frankfurt School and Jürgen Habermas theory). Therefore, the notions of ideology, power, hierarchy and gender together with sociological variables are considered as relevant for an interpretation or explanation of text (Wodak \& Meyer, 2001).

In addition to CDA, RRG takes serious interest in the creation of the common conception, describing different languages as well as trying to build cross-linguistic studies. For this purpose, a special analytical tool has been created. It is known as Aktionsart that is based on Vendler's classification of verbs (Vendler, 1967) with Dowty's addition (Filip, 2009: 1197).

RRG supporters offer a series of tests allowing to define Aktionsart types (see Appendix 1). Detailed investigation of all the tests allows us to develop definition related to a verb class objectively. Furthermore, it enables us to identify semantic macroroles. As Van Valin proves that there are semantic macroroles: actor and undergoer (Van Valin, 2007: 37); his version of macroroles association is presented in Appendix 2., so, we can compute the semantic representation of a sentence.

The key feature of RRG is that it describes all languages according to the scheme represented. However, the implementation of RRG in the Russian language has proven to be rather problematic. Despite the obvious presence of the Russian language as an object of the analysis (e.g. Van Valin, 1993), little research undertake to outline the complete work devoted to RRG application in Russian context. Unfortunately, only few researchers have addressed the issue. Despite our thorough search, we have managed to find isolated works by Padusheva that deserves attentions. Although her approach highlights the importance of assessment practices it does not provide a complete description of RRG in Russia. In her study, Padusheva refers frequently to RRG, but she treats it as an example or illustration element for her own hypothesis, that fails detailed and deep consideration (Padusheva, 1996, 2009a, 2009b). Padusheva's RRG version for Russian is presented in Appendix 3.

Thus, the main problems in the RRG application within interdisciplinary researches in Russia are evident:

- detailed description of RRG in Russian context for a wide range of representatives of social sciences has been neglected;

- $\quad \mathrm{RRG}$ is not yet established as an interdisciplinary approach that limits the possibilities of its usage.

There is general methodological dissatisfaction among the social science representatives with the accuracy of CDA as it reveals features of subjectivity. In this regard, RRG with its rigidity and tests independent of the researcher is viewed as an interesting prospect.

The main purpose of this work is to carry out the analysis of the transcript excerpt (see Appendix 7). The choice of the transcript for detailed investigation is explained by the fact that many social sciences have developed qualitative methods of research only. However, the qualitative methodology contains some evident signs of subjective interpretations. We believe that RRG can allow us to reduce the level subjectivity in the approach.

\section{Data and method}

We analyzed a transcript excerpt extracted from the tape recorded at Pedagogical council meeting at one of the secondary schools in St. Petersburg. The choice of the material can be explained by the presence of essential features, typical for educational process, that represent real conflicts discussed in the paper.

It is a wider knowledge that teaching at a secondary school in Russia reflects the features of conservatism. It explains why inclusive education can be evaluated as an inadequate pedagogical innovation. In the current study, we take a closer look at the real face to face discussion that occurs between the alleged teacher of inclusive education and the deputy principal. The discussion is initiated by discontented parents and results in conflict. Two groups of parents - the parents of children with special needs and the parents of healthy children - express different opinions about the way the inclusive programme has been introduced at school their children attend. The alleged teacher, who is working on inclusive education program, and the school deputy principal try to provide support to different groups of parents. We make an attempt to illustrate how participants involved in conflict reflect on the same situation in their personal discursive practices.

The transcript is presented in Russian. The average length of the alleged teacher's moves calculate 5.33 words in addition to deputy principal's moves, which calculate 6.25 words.

Firstly, the predicates are identified; they are proved to be verbs in all cases. This point brings us to the next stage, we determine the Aktionsart for each predicate used in the tests. At the next stage, the macroroles are established.

\section{Role and Reference Grammar (RRG-based) Analysis}

This section deals with the comparative analysis of two short speech extracts recorded at Pedagogical council's meeting. At this stage the transcript excerpts are presented with underlined predicates, Aktionsart, Logical Structure and Macroroles. List of data is presented in Appendix 4. The carried-out tests aimed at developing definition of the Logical Structure for each predicate presented in Appendix 5. 
The alleged teacher of inclusive education

1) Мы (учителя) будем учить особых детей в нашей школе / We (teachers) will teach children with special needs in our school

Учumь / Uchit'/ Teach: causative accomplishment

[do' (we, Ø)] CAUSE [BECOME znat'/know' (children with special needs )]

Macroroles: 2; we (teachers) = actor, children with special needs = undergoer

Teachers are obliged with responsibilities for the learning process and perform as actors who will teach. Children with special needs play the role of object of teaching. Children represent the object towards which the action is directed.

Nevertheless, inconsiderable change in sentence wording would lead to the change in the manner of stating the arguments and respectively the function of other macroroles:

1.1) We (teachers) will teach the subjects to children with special needs

Macroroles: 2; we (teachers) = actor, subjects = undergoer

This example illustrates the lack of specific macrorole applied to children with special needs.

The analysis of semantic macroroles enable us to apply additional assessment technique to analyze participants' points of views on the teaching process, which might be presented implicitly in discourse practices.However, the comparison of the provided examples (1) and (1.1.) clearly indicate the need to avoid the direct sociological interpretations which are based on the non-linguistic concept of the (social) roles.

2) Родители (особых детей) ждут наших активных действий The parents (of children with special needs) wait for our drastic actions

Ждать/Zdat'/Wait: state

Zdat'Wait' (parents, actions)

Macroroles: 2; parents $=$ actor, actions $=$ undergoer.

In the following sentence parents (of children with special needs) play an actor macrorole, despite the fact that they wait for teachers' actions only. The second macrorole in English is marked by a prepositional phrase in the form of predicate. However, the identical structural phrases in Russian do not require a preposition in the similar position. To encode a macrorole in Russian language direct argument is used accordingly.

3) Они (родители особых детей) заполнили анкету / They (the parents of children with special needs ) had filled in a questionnaire

Заполнить / had filled in: causative accomplishment

[do' (they (the parents of children with special needs ), Ø)] CAUSE [BECOME zapolnena'/filled' (questionnaire)]

Macroroles: 2; they (the parents of children with special needs ) $=$ actor, questionnaire $=$ undergoer

Parents of children with special needs accomplish an actor`s macrorole. However, in this sentence the parents`actor`s macrorole only involves filling in a questionnaire, that evidently conducts a real action because it shows the parents' ability to support the inclusive program. Thus, in this sentence the alleged teacher of inclusive education indirectly reports on parents of children with special needs intention and focuses on the action while introducing the inclusive programme.

\section{The deputy principle}

4) Родители (здоровых детей) пришли ко мне / The parents (of healthy children) had come to me Приходить / prihodit' / come: active accomplishment do' (parents, [prihodit'/come * parents, me (deputy principle))]) \& INGR prishli'/had come' (me /deputy principle)

Macroroles: 2; parents $=$ actor, me $($ deputy principle $)=$ undergoer

In this sentence the deputy principle positions herself as undergoer, and parents perform as the actors. The deputy principle pronounces the verb «come». In Russian interpretation "come" means not only that parents go to somewhere or act movements; and come to the deputy principle or approach her/him, but also that they make claims or demand. They had come to the deputy principle to report about some problems which were the cause of dissatisfaction. Thus, the deputy principle emphasizes active actions of healthy children's parents and associates them with dissatisfaction. 
5) Также они (родители здоровых детей) говорили директору / Also they (parents of healthy children) talked to the principal

говорить/govorit'/to tell: activity.

do' (they (parents of healthy children), [govorit'/ tell' (they (parents of healthy children), principal)])

Macroroles: 2; they (parents) $=$ actor, principal = undergoer

The above example shows the similar situation as in (4). The deputy principle positions the principal as undergoer, and the parents as the actors, but this grammatical structure does not allow us to talk about the resulted parents actions. The second macrorole in English is marked by a prepositional phrase as predicate. However, the Russian structure does not require a preposition in the similar position in the sentence. Therefore we admit it to be a direct argument that encodes a macrorole. From a political point of view, a direct face to face conversation, conducted between the parents of healthy children and the principal, informs us of a serious conflict situation (relevant to Russian traditions).

At the same time, neither in the first sentence (4) nor in the second one (5) the deputy principle mentions something about what kind of conflict takes place. Both sentences emphasize only the sharpness of the conflict and the extremely active role on behalf of the parents.

6) Они бомбардируют РОНО, чтобы иметь нормальное образование в нормальном классе / Тheу «bombard» (verbal attack) the local government education office to obtain the normal education in the normal environment

Бомбардировать/bombardirovat'/to bombard (main verb): activity.

do' (they (parents of healthy children), [bombardirovat'/ bombard' (they (parents of healthy children), the local government education office)])

Macroroles: main clause, 2; they (parents of healthy children) = actor, the local government education office $=$ undergoer

The deputy principle keeps on discussing the conflict problem and uses a verb «bombard» in her answer. Applying the verbs «come», «tell» and «bombard» later in the dialogue, she describes the conflict situation and finally reveals the cause. She states that parents of healthy children believe that introduction of inclusive education will not allow their children to get a normal education. The deputy principle continues to position the local government education office as undergoer, and the parents as the actor. The choice of grammatical constructions helps to convey the meaning that she tries to decline all responsibilities for parents` opinion. All the highlighted problems are taken entirely as an initiative of healthy children parents. However, the grammatical structure used does not allow us to talk about the resulted action.

7) В этой ситуации я никого не убеждаю... / In this situation, I don't try to persuade anyone...

Убеждать /ubezhdat' (imperfect verbs) /try (main verb) to persuade: activity.

In Russian:

do’ (I (deputy principle), [ubezhdat' ( I, anyone)])

Macroroles: 2; I (deputy principle ) = actor, anyone = undergoer

In English:

do' (I, [try' ( I, anyone)]).

Macroroles: 2; I (deputy principle) $=$ actor, anyone $=$ undergoer

In the following sentence the deputy principle, finally, states her opinion, that is extremely negative in relation to the inclusive program. She does not try to persuade the parents of healthy children. However, the deputy principle does not mention the parents of healthy children directly, preferring to call them as «anyone». Speaking about own opinion, the deputy principle puts herself in a position of the actor`s macrorole, and the parents as «anyone» take a position of the undergoer's macrorole.

\section{Discussion and conclusion}

Application of RRG allows us to reveal some latent elements of the considered conflict situation. The current paper underlines various patterns of the role representations on behalf of the participants in conflict situation. The alleged teacher of inclusive education demonstrates her concern about the inclusive education development at school. In her small talk, the focus is placed on the teacher, who have to take an active position, and on the parents of children with special needs, despite their rather passive attitude. The results illustrate that while forming characteristics of the teachers position, the supporter of inclusive education employs a causative accomplishment verb type in her/his answers, considering teachers as the promoters of the program of inclusive education and sources of new knowledge provided to children with special needs. Hence, we can witness the evident signs of confidence from the deputy principal perspective while introducing the inclusive education program; moreover we can stress her resistance in accepting the situation as problematic. 
Although, the role of children with special needs and their parents is essentially diminished, children with special needs show no evidence in developing active position, moreover, they are treated as object of actions by other participants. The provided examples prove that they (children with special needs) are mentioned in the conversations by few participants of the conflict. Parents of children with special needs appear to play rather (passive) roles either. In the second sentence, a STATE verb is used, which transfer the meaning that parents simply wait, but without evident signs of further development of situation like fulfillment, result or act. The third sentence highlights the concern expressed by parents of children with special needs. In this respect CAUSATIVE ACCOMPLISHMENT verb type is used and characterizes parents as the initiators of the actions. However the action is implied only in the questionnaire and, therefore, it stresses parents' passive position more evidently.

The speech of the deputy principal is totally different in manner. She aims at declining all her responsibility for disagreements, and frequently places the parents of healthy children in a position of the actor' macrorole. In order to succeed she overuses the verbs of ACTIVITY and ACTIVE ACCOMPLISHMENT types.

It is worth noting that the deputy principal does not have intention to report directly on the unwillingness to introduce the inclusive education program. Therefore, she applies for the opinion to healthy children parents. She describes the current conflict situation by manipulating with verbs «come», «tell» and «bombard» in her speculation about the cause of conflict. So, healthy children's parents believe that the introduction of inclusive education will not allow their children to get a normal education. The lexical item "normal" might be interpreted like inclusive educations is abnormal.

One of the essential advantages of the performed analysis is that we have the opportunity to compare the deputy principal 's opinion when placed in various social situations. Before the Pedagogical meeting we managed to receive a semi-structured complete interview with the deputy principal (see Appendix 7). She gave the following answer to our question: «What do you think about the introduction of inclusive education at your school?»

I share extremely positive attitude towards the introduction of inclusive education. In our city the "Available Environment» program is being realized nowadays. I completely support this program and I consider it as an urgent need in our district. At our school there are 12 children who are children with special needs. I think that the introduction of inclusive education will increase their opportunities for development. Also, in the future, we will be able to accept more children with special needs ...

The RRG-based analysis suggests that the last sentence "In this situation, I don't try to persuade anyone" neglects any support towards the inclusive programme. Moreover, with this phrase, the deputy principal closes the meeting, without giving additional explanations and without pledging the word to the supporters of inclusive education. Her speech shows that she has already decided to support parents of healthy children and shares their fears that the school can become «abnormal» after the introduction of inclusive education.

Overall, both sides involved in conflict consider their opinions as the only true, ignoring the existence of the issue. Two opposing groups of parents can be recognized by those teachers who are familiar with the conflict. Considering the fact that the deputy principal has powerful administrative authority, it is possible to assume that the school might deny the introduction of inclusive education because of the strong objections on behalf of healthy children`s parents.

The primary goal of the paper is to show, whether RRG can improve the issue of objectivity in the transcripts`analysis of social research in conflict situations. Our research has proved our hypothesis and showed that RRG can be used as an instrument for identification the latent elements of self-presentation, and for representation the situation by the participants in the conflict. It allows us to conclude that future research should apply RRG in an interdisciplinary context.

It is evident that RRG approach can not be used solely as the research method for conflicts in inclusive education. The procedure of conflict analysis by implementing multimodal methods offers a lot of perspectives for further investigations. In our study, RRG helps to reveal the sincere opinion and true intentions expressed by the deputy principal. Notwithstanding, it becomes possible only in combination with another methodological tool - a semistructured deep interview. It is clear that RRG could promote the increase of objectivity of the analysis of transcripts in qualitative social research. Moreover, it should be noted that RRG provides new information which in combination with other methods can increase our understanding of the positions of participants involved in a conflicts.

\section{Acknowledgments}

The author(s) declared no potential conflicts of interest with respect to the research, authorship, and/or publication of this article. The author(s) received no financial support for the research, authorship, and/or publication of this article.

\section{References}

Alehina, S.V. (2012a). Challenges and tendencies of school inclusive practice in Russian education. Kursk: Regional Open Social Institute, Russia.

Alehina, S.V. (2012b). Inclusive education in Russia: State and development trends. Moscow, Russia. 
Butenko, A. \& Chistokhina, A. (2015). Inclusion education: analysis of Russian teachers' expectations and important aspects of school personnel training. Revista Electrónica Interuniversitaria de Formación del Profesorado, 18 (1), 201-209.

Dowty, D. R. (1979). Word Meaning and Montague Grammar. The Semantics of Verbs and Times in Generative Semantics and in Montague's PTQ. Dordrecht (Holland): Reidel

Filip, H. (2009). Aspectual class and Aktionsart. Retrieved from: http://user.phil-fak.uniduesseldorf.de/ filip/filip.handbook.2011.pdf. (10/05/2015)

Godovnikova, D. (2009). The conditions for the integrated education of children with impaired development. Russian Education and Society, 51(10), 26-39.

Iarskia-Smirnova, E. (1999). What the Future Will Bring I Do Not Know: Mothering Children with Disabilities in Russia and the Politics of Exclusion. Frontiers: A Journal of Women's Studies 20 (2): 68-86

Iarskia-Smirnova, E. (2001). Social Change and Self-Empowerment: Stories of Disabled People in Russia. Disability and the Life Course: Global Perspectives, ed. Mark Priestley. Cambridge: Cambridge University Press, 101-112.

Korkunov, V.V., Nigayev, A.S., Reynolds, L.D., \& Lerner, J.W. (1998). Special education in Russia: History, reality, and prospects. Journal of Learning Disabilities, 31(2), 186-192

Malinina, T.B., Dadianova, I.B., Tarando, E.E., Pruel, N.A., Malychev,V.A. (2015), Information presentation of professional structure of Russian society in mass media. Review of European Studies, 7(9), 41-59.

Martianova, N. A. \& Rubtcova, M. V. (2013). Professionals and Clients: Struggle for Dominance in Conditions of Musical Inclusive Education. Historical, philosophical, political and legal sciences, cultural studies and art history. Theory and Practice. Tambov: Gramota, 11(37), Part II, 152-155.

MK, (2015) Official site of the «Moskovsky Komsomolets» newspaper http://www.mk.ru/social/2014/10/25/moskovskie-roditeli-proveli-ocherednuyu-akciyu-protesta.html (10/05/2016)

Padučeva, E. V. (1996) Semantičeskie issledovaniâ: Semantika vremeni i vida v russkom âzyke. Semantika narrativa. Moskva: Âzyki rus. kul'tury

Padučeva, E.V. (2009a.) Struktura Sobytiâ: Semantičeskie Roli, Aspektual"nost", Kauzaciâ. Naučno-tehničeskaâ informaciâ. Seriâ 2: Informacionnye processy i sistemy. 6: 38-44.

Padučeva, E.V. (2009b). Leksičeskaâ aspektual"nost" i klassifikaciâ predikatov po Maslovu - Vendleru (On lexical aspect and the Maslov-Vendler verbal taxonomy). Voprosy âzykoznaniâ. 6:3-20.

Paducheva, E.V. (2003) Is there an "anticausative" component in the semantics of decausatives? Journal of Slavic Linguistics, 11(1), 173-198.

Pavenkov, O. V, Pavenkov, V., \& Rubtcova, M. V. (2015a). The altruistic behavior: characteristic of future teachers of inclusive education in Russia. Procedia - Social and Behavioral Sciences. http://dx.doi.org/10.1016/j.sbspro.2015.03.003

Pavenkov, O., Rubtcova, M., Pavenkov, V., \& Vasilieva, E. (2015b). The language of altruism: Corpus-based conceptualisation of social category for management sociology. Asian Social Science, 11(13), 289-297. http://dx.doi.org/10.5539/ass.v11n13p289

Raymond, P. D. (1989). Disability as Dissidence: The Action Group to Defend the Rights of the Disabled in the USSR. In The Disabled in the Soviet Union: Past and Present, Theory and Practice, ed. William O. McCagg and Lewis Siegelbaum. Pittsburgh: University of Pittsburgh Press: 235-252.

RCD, (2015). Website of the Russian Society of the Deaf: http://www.voginfo.ru/novosti/deafland/item/922FGOS.html (25/10/2016)

Rubtcova, M., Pavenkov, O., Pavenkov, V., Martianova, N. \& Martyanov, D. (2015a). Deprofessionalisation as a Performance Management Dysfunction: The Case of Inclusive Education Teachers in Russia. Asian Social Science. 11(18), 339-349. http://dx.doi.org/10.5539/ass.v11n18p339

Rubtcova, M., Pavenkov, O., Khmyrova-Pruel, I.,Malinina, T., \& Dadianova, I. (2016). Systemic functional linguistics (SFL) as sociolinguistic and sociological conception: Possibilities and limits of theoretical framework. International Journal of Applied Linguistics and English Literature, 5(3), 272-281.

Rubtsova, M.V., Kapustkina, E., Karapetyan, R., Kovalev, I., \& Rasskazov, S. (2015). The social environment and business communication in English: A small-scale research on front-line staff performance in Russia, Spain and France. International Review of Management and Marketing, 5(4), 253-258.

Ruiz Ruiz, J. (2009). Sociological Discourse Analysis: Methods and Logic [71 paragraphs]. Forum Qualitative Sozialforschung / Forum: Qualitative Social Research, 10(2), Art. 26.

Roza, D. (2005). Inclusive education in Russia: A status report. Disability World, 27.

Smith-Davis, J. (2000). People with Disabilities in Russia: Progress and Prospects. In Cross-Cultural Perspectives on Quality of Life, ed. Kenneth D. Keith \& Robert L. Schalock. Washington, D.C.: American Association on Mental Retardation: 219-229. 
Thomson, K. (2006). Disability Organizations in the Regions. In Russian Civil Society: A Critical Assessment, ed. Jr. Alfred B Evans, Laura A. Henry and Lisa McIntosh Sundstrom. New York: M.E. Sharpe: 229-245.

Van Dijk, T. A. (2009). Critical discourse studies: a sociocognitive approach. In Wodak, R. \& Meyer M. (Eds.), Methods of Critical Discourse Analysis, 1-33 London: Sage

Van Dijk, T. A. (2013). Discourse and Power. Moskva: The book house, Librokom

Van Valin, R. D. Jr. (1993). A synopsis of Role and Reference Grammar. In Advances in role and reference grammar, / Van Valin, ed ., 1-64. John Benjamins Publishing Company

Van Valin, R.D. Jr. \& LaPolla R. J. (1997). Syntax, Structure, Meaning and Function. Cambridge: Cambridge University Press

Van Valin, R.D. Jr. (2005). Exploring the Syntax-Semantics Interface. Cambridge: Cambridge University Press

Van Valin, R. D. Jr. (2007). The Role and Reference Grammar Analysis of Three-Place Predicates. Suvremena Lingvistika, 63(1),31-64.

Vendler, Z. (1967). Linguistics in Philosophy. Ithaca, N. Y.: Cornell Univ. Press.

Wodak, R. \& Meyer, M. (eds.) (2001). Methods of Critical Discourse Analysis. London: Sage.

Appendix 1. Tests for the determining of verb classes (Adapted from Van Valin, 2005: 39 by Dr.R. Jiménez Briones, UAM)

\begin{tabular}{|c|c|c|c|c|c|c|c|c|}
\hline & TEST 1 & TEST 2 & TEST 3 & $\begin{array}{l}\text { TEST } \\
4\end{array}$ & TEST 5 & $\begin{array}{l}\text { TEST } \\
6\end{array}$ & $\begin{array}{l}\text { TEST } \\
7\end{array}$ & $\begin{array}{l}\text { TEST } \\
8\end{array}$ \\
\hline Class & $\begin{array}{l}\text { What } \\
\text { happened? }\end{array}$ & Progressive & $\begin{array}{l}\text { Dynamic } \\
\text { adv }\end{array}$ & $\begin{array}{l}\text { Pace } \\
\text { adv }\end{array}$ & $\begin{array}{l}\text { For an } \\
\text { hour }\end{array}$ & $\begin{array}{l}\text { In an } \\
\text { hour }\end{array}$ & $\begin{array}{l}\text { Stative } \\
\text { Mod }\end{array}$ & cause \\
\hline State & No & $\mathrm{No}^{*}$ & No & No & Yes $^{*}$ & No & Yes & No \\
\hline Activity & Yes & Yes & Yes & Yes & Yes & No & No & No \\
\hline Accomplishment & Yes & Yes & No & Yes & Irrelev* & Yes & Yes & No \\
\hline Achievement & Yes & $\mathrm{No}^{*}$ & No & $\mathrm{No}^{*}$ & $\mathrm{No}^{*}$ & $\mathrm{No}^{*}$ & Yes & No \\
\hline Semelfactive & Yes & $\mathrm{No}^{*}$ & $\mathrm{No}^{*}$ & $\mathrm{No}^{*}$ & Yes $^{*}$ & $\mathrm{No}^{*}$ & No & No \\
\hline $\begin{array}{l}\text { Active } \\
\text { Accomplishment }\end{array}$ & Yes & Yes & Yes & Yes & Irrelev* & Yes & Yes & No \\
\hline Causative state & $\mathrm{No}^{*}$ & Yes $^{*}$ & Yes $^{*}$ & No & Yes & No & Yes & Yes \\
\hline $\begin{array}{l}\text { Causative } \\
\text { activity }\end{array}$ & Yes & Yes & Yes & Yes & Yes & No & Yes & Yes \\
\hline $\begin{array}{l}\text { Causative } \\
\text { accomplishment }\end{array}$ & Yes & Yes & Yes $^{*}$ & Yes & Irrelev. * & Yes & Yes & Yes \\
\hline $\begin{array}{l}\text { Causative } \\
\text { achievement }\end{array}$ & Yes & No & Yes $^{*}$ & $\mathrm{No}^{*}$ & No & $\mathrm{No}^{*}$ & Yes & Yes \\
\hline $\begin{array}{l}\text { Causative } \\
\text { semelfactive }\end{array}$ & Yes & $\mathrm{No}^{*}$ & Yes* & $\mathrm{No}^{*}$ & $\mathrm{No}^{*}$ & $\mathrm{No}^{*}$ & No & Yes \\
\hline $\begin{array}{l}\text { Causative } \\
\text { active } \\
\text { accomplishment }\end{array}$ & Yes & Yes & Yes & Yes & Irrelev. ${ }^{*}$ & Yes & Yes & Yes \\
\hline
\end{tabular}

$(*=$ with some exceptions) 


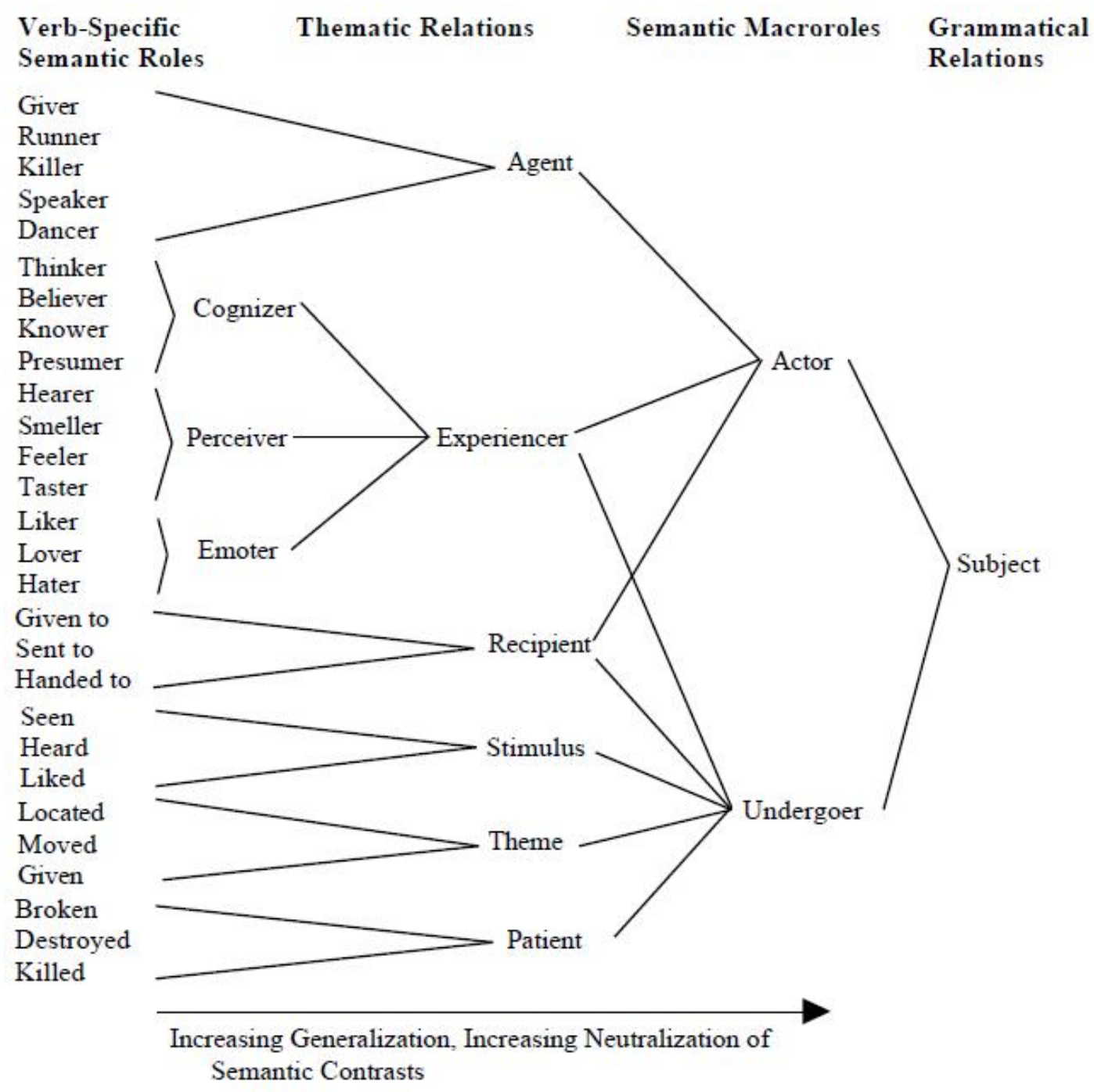

Appendix 3. Vendler's classification of verbs in the Russian language. Padusheva's adaptation of some elements of the RRG conception to Russian (Padučeva, 2009b:3; Padučeva, 1996: 91-92)

\begin{tabular}{|l|l|l|l|l|}
\hline $\begin{array}{l}\text { Vendler's classification } \\
\text { of verbs }\end{array}$ & $\begin{array}{l}\text { Padusheva's } \\
\text { classification of verbs in } \\
\text { the Russian language }\end{array}$ & Progressive & PP-for & PP-in \\
\hline STATES & States & & + & \\
\hline ACTIVITIES & $\begin{array}{l}\text { Activities and non-limiting } \\
\text { processes }\end{array}$ & + & + & - \\
\hline ACCOMPLISHMENTS & $\begin{array}{l}\text { Actions and limiting } \\
\text { processes }\end{array}$ & $\begin{array}{l}+(\text { imperfective } \\
\text { verb) }\end{array}$ & $\begin{array}{l}+(\text { (imperfective } \\
\text { verb) }\end{array}$ & $\begin{array}{l}+ \text { (perfective } \\
\text { verbs) }\end{array}$ \\
\hline ACHIEVEMENTS & $\begin{array}{l}\text { Jump (abrupt change) and } \\
\text { immediate transitions }\end{array}$ & - & - & $\begin{array}{l}(+) \\
\text { (perfective } \\
\text { verbs) }\end{array}$ \\
\hline
\end{tabular}


St. Petersburg, 26.05.2015, duration $42 \mathrm{~min}$

Fragment, 41-42th min, before end

\begin{tabular}{|c|c|c|c|}
\hline \multicolumn{2}{|l|}{ Alleged teacher of inclusive education } & \multicolumn{2}{|l|}{ The deputy principal of the school } \\
\hline $\begin{array}{l}\text { Mы (учителя) будем учить особых детей в } \\
\text { нашей школе / We (teachers) will teach } \\
\text { children with special needs in our school }\end{array}$ & $\begin{array}{l}8 \\
\text { words / } \\
34 \text { sign }\end{array}$ & $\begin{array}{l}\text { Родители (здоровых детей) пришли } \\
\text { ко мне (The parents (Healthy children) } \\
\text { had come to me) }\end{array}$ & $\begin{array}{l}4 \text { words / } \\
19 \text { sign }\end{array}$ \\
\hline $\begin{array}{l}\text { Родители (особых детей) ждут наших } \\
\text { активных действий (The parents (of children } \\
\text { with special needs) wait for our active actions) }\end{array}$ & $\begin{array}{l}5 \\
\text { words / } \\
33 \text { sign }\end{array}$ & $\begin{array}{l}\text { Также они говорили директору } \\
\text { (Also they talked to the principal) }\end{array}$ & $\begin{array}{l}4 \text { words / } \\
25 \text { sign }\end{array}$ \\
\hline $\begin{array}{l}\text { Они (родители особых детей) заполнили } \\
\text { анкету (They (The parents of children with } \\
\text { special needs) had filled in a questionnaire) }\end{array}$ & $\begin{array}{l}3 \\
\text { words / } \\
18 \text { sign }\end{array}$ & $\begin{array}{l}\text { Они бомбардируют РОНО, чтобы } \\
\text { иметь нормальное образование в } \\
\text { нормальном классе (They bombard } \\
\text { the local government education office } \\
\text { to obtain the normal education in the } \\
\text { normal environment) }\end{array}$ & $\begin{array}{l}10 \text { words } \\
/ 68 \text { sign }\end{array}$ \\
\hline & & $\begin{array}{l}\text { В этой ситуации я никого не } \\
\text { убеждаю (In this situation, I don't try } \\
\text { to persuade anyone) }\end{array}$ & $\begin{array}{l}7 \text { words / } \\
29 \text { sign }\end{array}$ \\
\hline Total & $\begin{array}{l}16 \\
\text { words / } \\
85 \text { sign }\end{array}$ & & $\begin{array}{l}25 \text { words } \\
/ 141 \text { sign }\end{array}$ \\
\hline The average length & $\begin{array}{l}5.33 \\
\text { words / } \\
28.33 \\
\text { sign }\end{array}$ & & $\begin{array}{l}6.25 \\
\text { words } \\
35.25 \\
\text { sign }\end{array}$ \\
\hline
\end{tabular}

Appendix 5. Definition of the verb classes in the studied examples

1) Преподавать/ teach

\begin{tabular}{|c|c|c|}
\hline \multicolumn{3}{|l|}{ Преподавать / to teach } \\
\hline TEST 8. Cause & $\begin{array}{l}\text { Мы будем причиной знаний } \\
\text { студентов / We will be the cause of } \\
\text { students`knowledge }\end{array}$ & + \\
\hline $\begin{array}{l}\text { TEST 1. What happened? } \\
\text { What's going on? }\end{array}$ & $\begin{array}{l}\text { Мы будем учить / We (teachers) will } \\
\text { teach }\end{array}$ & + \\
\hline TEST 2. Progressive & Мы учим / We are teaching & + \\
\hline TEST 3. Dynamic adv & $\begin{array}{l}\text { Мы будем учить энергично / We will } \\
\text { teach vigorously }\end{array}$ & + \\
\hline TEST 4. Pace adv & $\begin{array}{l}\text { Мы будем учить постепенно/ We } \\
\text { will teach gradually }\end{array}$ & + \\
\hline TEST 5. For an hour & $\begin{array}{l}\text { Мы будем учить в течение часа / } \\
\text { *We will teach for an hour }\end{array}$ & $\begin{array}{l}+ \text { in Russian } \\
? \text { in English }\end{array}$ \\
\hline TEST 6. In an hour & $\begin{array}{l}\text { Мы будем учить за час / We will } \\
\text { teach in an hour }\end{array}$ & + \\
\hline TEST 7. Stative Mod & $\begin{array}{l}\text { Учащие учителя / The teaching } \\
\text { teachers }\end{array}$ & + \\
\hline Class & causative accomplishment & \\
\hline
\end{tabular}




\begin{tabular}{|c|c|c|}
\hline \multicolumn{3}{|l|}{ Ждать /to wait } \\
\hline TEST 8. Cause & $\begin{array}{l}\text { Мы являемся причиной ожидания } \\
\text { наших активных действий / We are } \\
\text { the cause of waiting of our active } \\
\text { actions }\end{array}$ & - \\
\hline $\begin{array}{l}\text { TEST 1. What happened? } \\
\text { What's going on? }\end{array}$ & *Родители ждут / *The parents wait & - \\
\hline TEST 2. Progressive & *Родители ждут / *The parents wait & - \\
\hline TEST 3. Dynamic adv & $\begin{array}{l}\text { *Родители ждут энергично / *The } \\
\text { parents wait vigorously }\end{array}$ & - \\
\hline TEST 4. Pace adv & $\begin{array}{l}\text { *Родители ждут постепенно/ *The } \\
\text { parents wait gradually }\end{array}$ & - \\
\hline TEST 5. For an hour & $\begin{array}{l}\text { Родители ждут в течение часа / The } \\
\text { parents have been waiting for an hour }\end{array}$ & + \\
\hline TEST 6. In an hour & $\begin{array}{l}\text { *Родители ждут за час / *Parents } \\
\text { wait in an hour }\end{array}$ & - \\
\hline TEST 7. Stative Mod & $\begin{array}{l}\text { Ждущие родители / The waiting } \\
\text { parents }\end{array}$ & + \\
\hline Class & State & \\
\hline
\end{tabular}

3) заполнили /had filled in

\begin{tabular}{|c|c|c|}
\hline \multicolumn{3}{|l|}{ Заполнять / To fill } \\
\hline TEST 8. Cause & $\begin{array}{l}\text { Родители были причиной } \\
\text { заполнения анкеты / parents were the } \\
\text { cause of filling in the questionnaire }\end{array}$ & + \\
\hline $\begin{array}{l}\text { TEST 1. What happened? } \\
\text { What's going on? }\end{array}$ & $\begin{array}{l}\text { Родители заполнили / The parents } \\
\text { had filled in the questionnaire }\end{array}$ & + \\
\hline TEST 2. Progressive & $\begin{array}{l}\text { Родители заполняют анкету/ parents } \\
\text { are filling in the questionnaire }\end{array}$ & + \\
\hline TEST 3. Dynamic adv & $\begin{array}{l}\text { Родители заполнили анкету } \\
\text { энергично / parents had filled in a } \\
\text { questionnaire vigorously }\end{array}$ & + \\
\hline TEST 4. Pace adv & $\begin{array}{l}\text { Родители заполнили анкету } \\
\text { постепенно/ parents had filled in a } \\
\text { questionnaire gradually }\end{array}$ & + \\
\hline TEST 5. For an hour & $\begin{array}{l}\text { Родители заполнили анкету в } \\
\text { течение часа / * parents had filled in a } \\
\text { questionnaire for an hour }\end{array}$ & $\begin{array}{l}+ \text { in Russian } \\
? \text { in English }\end{array}$ \\
\hline TEST 6. In an hour & $\begin{array}{l}\text { Родители заполнили анкету за час / } \\
\text { parents had filled in a questionnaire in } \\
\text { an hour }\end{array}$ & + \\
\hline TEST 7. Stative Mod & $\begin{array}{l}\text { Заполнившие анкету родители / The } \\
\text { filled parents }\end{array}$ & $\begin{array}{l}+ \text { in Russian } \\
\text { - in English }\end{array}$ \\
\hline Class & causative accomplishment & \\
\hline
\end{tabular}




\begin{tabular}{|c|c|c|}
\hline \multicolumn{3}{|l|}{ пришли / То соте } \\
\hline TEST 8. Cause & $\begin{array}{l}\text { Родители были причиной прихода } \\
\text { ко мне / Parents were the cause of the } \\
\text { coming to me }\end{array}$ & - \\
\hline $\begin{array}{l}\text { TEST 1. What happened? } \\
\text { What's going on? }\end{array}$ & $\begin{array}{l}\text { Родители пришли / The parents had } \\
\text { come }\end{array}$ & + \\
\hline TEST 2. Progressive & $\begin{array}{l}\text { Родители приходят/ The parents are } \\
\text { coming }\end{array}$ & + \\
\hline TEST 3. Dynamic adv & $\begin{array}{l}\text { Родители пришли энергично / The } \\
\text { parents had come vigorously }\end{array}$ & + \\
\hline TEST 4. Pace adv & $\begin{array}{l}\text { Родители пришли постепенно/ The } \\
\text { parents had come gradually }\end{array}$ & + \\
\hline TEST 5. For an hour & $\begin{array}{l}\text { Родители пришли в течение часа / * } \\
\text { The parents had come for an hour }\end{array}$ & $\begin{array}{l}+ \text { in Russian } \\
? \text { in English }\end{array}$ \\
\hline TEST 6. In an hour & $\begin{array}{l}\text { Родители пришли за час / The parents } \\
\text { had come in an hour }\end{array}$ & + \\
\hline TEST 7. Stative Mod & Пришедшие родители / came parents & $\begin{array}{l}+ \text { in Russian } \\
\text { - in English }\end{array}$ \\
\hline Class & Active accomplishment & \\
\hline
\end{tabular}

5) говорили/talked

\begin{tabular}{|c|c|c|}
\hline \multicolumn{3}{|l|}{ говорить / To talk } \\
\hline TEST 8. Cause & $\begin{array}{l}\text { *Они были причиной разговора с } \\
\text { директором/*They were the cause of } \\
\text { conversation with the principal }\end{array}$ & - \\
\hline $\begin{array}{l}\text { TEST } 1 . \text { What happened? } \\
\text { What's going on? }\end{array}$ & Они (по)говорили / They talked & + \\
\hline TEST 2. Progressive & $\begin{array}{l}\text { Они говорят (в данный момент)/ } \\
\text { They are talking }\end{array}$ & + \\
\hline TEST 3. Dynamic adv & $\begin{array}{l}\text { Они говорили с директором } \\
\text { энергично / They talked with the } \\
\text { principal vigorously }\end{array}$ & + \\
\hline TEST 4. Pace adv & $\begin{array}{l}\text { Они (по)говорили с директором } \\
\text { быстро/ They talked with the principal } \\
\text { quickly }\end{array}$ & + \\
\hline TEST 5. For an hour & $\begin{array}{l}\text { Они говорили с директором в } \\
\text { течение часа / They talked with the } \\
\text { principal for an hour }\end{array}$ & + \\
\hline TEST 6. In an hour & $\begin{array}{l}\text { * Они говорили с директором за час } \\
\text { / } \text { They talked with the principal in an } \\
\text { hour }\end{array}$ & - \\
\hline TEST 7. Stative Mod & $\begin{array}{l}\text { Говорившие родители / *the talked } \\
\text { parents }\end{array}$ & $\begin{array}{l}+ \text { in Russian } \\
\text { - in English }\end{array}$ \\
\hline Class & Activity & \\
\hline
\end{tabular}


6) бомбардируют / bombard

бомбардировать / Tо bombard

\begin{tabular}{|c|c|c|}
\hline TEST 8. Cause & $\begin{array}{l}\text { *Они были причиной } \\
\text { бомбардировки РОНО /* They were } \\
\text { the cause of the bombing of the local } \\
\text { government education office }\end{array}$ & - \\
\hline $\begin{array}{l}\text { TEST } 1 . \text { What happened? } \\
\text { What's going on? }\end{array}$ & $\begin{array}{l}\text { Они бомбардировали РОНО / They } \\
\text { bombard the local government } \\
\text { education office }\end{array}$ & + \\
\hline TEST 2. Progressive & $\begin{array}{l}\text { Они бомбардируют (в данный } \\
\text { момент) / They are bombarding }\end{array}$ & + \\
\hline TEST 3. Dynamic adv & $\begin{array}{l}\text { Они бомбардировали РОНО } \\
\text { энергично / They bombard the local } \\
\text { government education office } \\
\text { vigorously }\end{array}$ & + \\
\hline TEST 4. Pace adv & $\begin{array}{l}\text { Они бомбардировали РОНО быстро/ } \\
\text { They bombard the local government } \\
\text { education office quickly }\end{array}$ & + \\
\hline TEST 5. For an hour & $\begin{array}{l}\text { Они бомбардировали РОНО в } \\
\text { течение часа / They bombard the local } \\
\text { government education office for an } \\
\text { hour }\end{array}$ & + \\
\hline TEST 6. In an hour & $\begin{array}{l}\text { * Они бомбардировали РОНО за час } \\
/ \text { * They bombard the local government } \\
\text { education office in an hour }\end{array}$ & - \\
\hline TEST 7. Stative Mod & $\begin{array}{l}\text { Бомбардирующие родители / *the } \\
\text { bombarded parents }\end{array}$ & $\begin{array}{l}+ \text { in Russian } \\
\text { ?- in English }\end{array}$ \\
\hline Class & Activity & \\
\hline
\end{tabular}

7) В этой ситуации я никого не убеждаю (In this situation, I don't try to persuade anyone)

Убеждать / try to persuade

\begin{tabular}{|c|c|c|}
\hline TEST 8. Cause & $\begin{array}{l}\text { *Я не являюсь причиной убеждания } \\
\text { /* I am not the cause of trying to } \\
\text { persuade }\end{array}$ & - \\
\hline $\begin{array}{l}\text { TEST } 1 . \text { What happened? } \\
\text { What's going on? }\end{array}$ & $\begin{array}{l}\text { Я не убеждаю / I do not try to } \\
\text { persuade }\end{array}$ & + \\
\hline TEST 2. Progressive & $\begin{array}{l}\text { Я не убеждаю (в данный момент) / } \\
\text { I'm not trying to persuade }\end{array}$ & + \\
\hline TEST 3. Dynamic adv & $\begin{array}{l}\text { Я не убеждаю энергично / I do not try } \\
\text { to persuade (vigorously) }\end{array}$ & + \\
\hline TEST 4. Pace adv & $\begin{array}{l}\text { Я не убеждаю постепенно } \\
\text { (медленно)/ I do not try to persuade } \\
\text { (slowly) }\end{array}$ & + \\
\hline TEST 5. For an hour & $\begin{array}{l}\text { Я не убеждаю в течение часа / I do } \\
\text { not try to persuade for an hour }\end{array}$ & + \\
\hline TEST 6. In an hour & $\begin{array}{l}* \text { Я не убеждаю за час /* I do not try } \\
\text { to persuade in an hour }\end{array}$ & $\begin{array}{l}\text { - } \\
\text { in Russian it is } \\
\text { possible as } \\
\text { informal lexis }\end{array}$ \\
\hline TEST 7. Stative Mod & $\begin{array}{l}\text { Убеждающий замдиректора / * Tried } \\
\text { to persuade vice director }\end{array}$ & $\begin{array}{l}+ \text { in Russian } \\
\text { ?- in English }\end{array}$ \\
\hline Class & Activity & \\
\hline
\end{tabular}


Appendix 6. The excerpt of transcript of the in-deep interview with the vice director

St. Petersburg, 15.04.2015, duration $14 \mathrm{~min}$

I. - interviewer

V. $\quad-\quad$ the deputy principal

Fragment, 5th min

I. К К Вак относитесь к введению инклюзивного образования в Вашей школе?

V. Я очень положительно отношусь $\kappa$ введению инклюзивного образования. В нашем городе реализуется программа "Доступная среда". Я полностью поддерживаю эту программу и считаю это насущной необходимостью в нашем районе. В нашей иколе обучается 12 детей, которые относятся к категории особых детей... (пауза) Я думаю, что внедрение инклюзивного образования повысит их возможности для развития. Также мы сможем принимать и других особых детей на обучение... (пауза)

Translating:

I. What do you think about the introduction of inclusive education at your school?

V. I share extremely positive attitude towards the introduction of inclusive education. In our city the "Available Environment» program is being realized nowadays. I completely support this program and I consider it as an urgent need. At our school there are 12 children who are children with special needs in our district. I think that the introduction of inclusive education will increase their opportunities for development. Also, in the future, we will be able to accept more children with special needs ...(pause) 